\title{
A Theory Based Model of Interpersonal Leadership: An Integration of the Literature
}

\author{
Kevan W. Lamm, Ph.D. \\ President \\ LR Brand, Inc. \\ Hannah S. Carter, Ph.D. \\ Associate Professor \\ Department of Agricultural Education and Communication, \\ Director Wedgworth Leadership Institute for Agriculture and Natural Resources \\ University of Florida \\ Alexa J. Lamm, Ph.D. \\ Assistant Professor \\ Department of Agricultural Education and Communication \\ Associate Director UF/IFAS Center for Public Issues Education \\ University of Florida
}

\begin{abstract}
Although the term interpersonal leadership has been well established within the literature, there remains a dearth of theoretically derived models that specifically address the comprehensive nature of the underlying leader behaviors and activities. The intent of the present article is to attempt to synthesize the existent leadership models, behaviors, and factors to arrive at a coherent conceptual model of interpersonal leadership that can inform efficient and effective leadership education programs. The resulting model included 13 primary factors integrated within a hierarchical framework. Leadership educators are recommended to adopt or adapt the proposed model while developing educational curriculum and interventions.
\end{abstract}

\section{Introduction}

At the most fundamental level, leadership requires an interaction between at least two individuals, where one "individual influences a group of individuals to achieve a common goal" (Northouse, 2013, p. 5). The interaction between leader and each respective follower therefore represents the most fundamental unit of the leadership process (Bass, 2008). In fact, for much of human history, leadership at an interpersonal level was all that was required to exert the influence necessary to achieve common goals (Diamond, 1999). Although rooted in historic necessity, interpersonal leadership remains critical for contemporary leaders (Rogers, 2003).

The need for interpersonal leadership development has been readily identifiable within the literature. For example, previous studies have found that there tends to be a gap between the soft, or interpersonal skills new university graduates possess relative to the skills necessary to be successful within an organization (AACSB, 2006; AACU, 2007). However, Brungardt (2011), 
found that even at a university where an undergraduate leadership certificate was offered, there were no significant soft skill proficiency differences among those that completed the certificate and those that did not.

Within the literature, there has been extensive research examining what a leader should embody. For example, studies have identified specific leader traits (e.g. Lord, De Vader, and Alliger, 1986), leader personality traits predicting leader outcomes (e.g. Judge \& Bono, 2000; Judge, Bono, Illies, \& Gerhardt, 2002), and leadership behaviors related to follower outcomes (e.g. MacKenzie, Podaskoff, \& Rich, 2001). However, there are a lack of literature based recommendations for how to go about developing interpersonal leadership capacity, "the field of leadership education needs to develop standardized leadership curriculum" (Brungardt, 2011, p. 16).

According to the National Leadership Education Research Agenda 2013 - 2018 priority area one identifies the need to "explore curriculum development frameworks to enhance the leadership education transfer of learning" (Andenoro et al., 2013). The purpose of the current article was to develop a theoretically derived conceptual model of interpersonal leadership concepts based on a comprehensive synthesis of the existing literature for use in leadership education settings.

\section{Leadership Classification Systems}

According to Bass (2008), "A simple model of leadership may be a list of different types of leaders grouped according to one or more characteristics about them. Taxonomy classifies them according to their mutual relationships, similarities, and differences" (p. 27). The use of theoretical leadership constructs or specific models of leadership to represent a set of leader behaviors or competencies have been employed extensively (Bass, 2008; Northouse, 2013). The use of classification terms such as taxonomy, model, or map must therefore be considered within a context and as a means to describe a certain phenomenon (Bass, 2008; Cheetham \& Chivers, 1996).

Numerous researchers have sought to establish taxonomy, a theory, or a model-based approach within which to classify leader behaviors, competencies, or outcomes (e.g. Bass, 2008). "Lacking a taxonomy of this sort, it seems unlikely that substantial progress can be made in the construction of leadership development programs and the generation of more effective models for understanding leader performance" (Fleishman et al., 1991, p. 246).

Based on the research of Fleishman, Mumford, Zaccaro, Levin, Korotkin, and Hein (1991) and their syntheses of the existent leadership literature four superordinate level categories were identified: information search and structuring, information use in problem solving, managing personnel resources, and managing material resources. The researchers then identified groupings of leader behavior, or competency, dimensions nested under each of the superordinate dimensions (Fleishman et al., 1991).

More recently Yukl, Gordon, and Taber (2002) completed a similar synthesis identifying primary leadership behavior categories and constituent components. The researchers identified 
three meta-categories of leader behavior or competencies: task, relations, and change. Similar to previous researchers (e.g. Fleishman et al., 1991) the researchers identified more discrete groupings of leadership behavior within each of the broader meta-categories (Yukl et al., 2002).

Within the broader context of leadership behavior taxonomic approaches, Bass (2008) identified nine broad behavioral categories: understanding, caring and consideration for others, communication competence, fostering and maintaining good relations, managing conflict, delegating and empowering, fostering happiness, promoting collective decision making, and personal attributes.

An extension of the taxonomic approach has been to also categorize leadership theories or models according to behavioral category level similarities, acknowledging that constituent parts of models and theories may not readily reside in only one category (Bass, 2008). For example, the individualized consideration component of transformational leadership may exist simultaneously at an individual, group, or organizational level it is the intent of the interpretation that is most germane (Avolio \& Bass, 1995).

An integration of the existent taxonomic research (Bass, 2008; Fleishman et al., 1991; Yukl et al., 2002) produced 24 thematically independent behavioral categories. The resultant categories were then aligned to a hierarchically appropriate level of leadership according to the original researchers' intent. In particular, levels of leadership were developed by synthesizing and thematically grouping previous taxonomic approaches available within the literature (Bass, 2008; Fleishman et al., 1991; Yukl et al., 2002).

\section{Interpersonal Leadership}

According to previous research and classification systems, the following behavioral categories were identified to guide a thorough analysis of the interpersonal leadership literature: understanding, caring and consideration for others (Bass, 2008), communication competence (Bass, 2008), fostering and maintaining good relations (Bass, 2008), managing conflict (Bass, 2008), delegating and empowering (Bass, 2008; Yukl et al., 2002), fostering happiness (Bass, 2008), promoting collective decision making (Bass, 2008), personal attributes (Bass, 2008), developing others (Fleishman et al., 1991; Yukl et al., 2002), recognizing others (Yukl et al., 2002), motivating others (Fleishman et al., 1991), encouraging innovative thinking (Yukl et al., 2002), and supporting others (Yukl et al., 2002). The existent taxonomic approaches were used as a grouping schema in a review of the literature. Resultant themes were grouped according to taxonomic category.

Personal attributes. The personal attributes of a leader and the nature of the directionality between traits and leadership have been well researched (e.g. Bass, 2008). There has even been an implicit attribution of leadership (Lord \& Maher, 1991) proposed. However, there are a number of recurrent themes. One of the primary themes has been that leaders must be a model for their followers (Bass \& Avolio, 1990; Burns, 1978; Har-Evan, 1992; Hunt, Boal, \& Sorenson, 1990; Kouzes \& Posner, 2002). For example, the idealized influence factor of transformational leadership has specifically identified the need for leaders to act in a manner which their follower may emulate (Bass \& Avolio, 1990). One of the areas in which leaders are 
expected to act as a model has been in their demonstration of ethical, moral, and value based judgments (George, 2003; Liden, Wayne, Zhao, \& Henderson, 2008; Walumbwa, Avolio, Gardner, Wernsing, \& Peterson, 2008). Given that leaders have been expected to act as change agents (Javidan \& Dastmalchian, 1993; Schein, 1995), and to take action (Winter, 1978) within their areas of influence the need for self-awareness is paramount (Mumford, Zaccaro, Harding, Jacobs, \& Fleishman, 2000; Walumbwa et al., 2008; Whitehead, 2009). A lack of leader humility (Van Dierendonck \& Nuijten, 2011; Wong \& Davey, 2007) has also been associated with an overly authoritative (Har-Evan, 1992) or even autocratic (Bass \& Farrow, 1977; Reddin, 1977) approach to leadership.

Given that leaders must also serve as a symbol for their followers or cause (Bolman \& Deal, 1991; Mintzberg, 1973) it has also been established that they require intelligence (Mumford et al., 2000), expertise (Barbuto \& Wheeler, 2006; Wilson, O'Hare, \& Shipper, 1990), and professional competence (Shrivastava \& Nachman, 1989; House, 1977). Additionally, given their role, leaders must have the confidence (House, 1977; Luthans \& Avolio, 2003) and courage (Van Dierendonck \& Nuijten, 2011) to act.

Leadership typically occurs within a complex and dynamic environment (Van Wart, 2003). Consequently, a leader must have command of multiple capacities to help span perceived boundaries (Hitt, Middlemist, \& Mathis, 1983) and respond to requirements accordingly (Sayles, 1981). Frequently, within the complexity of the context, the ability to lead others has required persuasion (Greenleaf, 1970; Har-Evan, 1992; Kirk \& Shutte, 2004; Stogdill, Goode, \& Day, 1962) and adaptability (Heifetz, 1994; Lord \& Maher, 1993; Luthans \& Avolio, 2003). Additionally, previous research has found that leaders must harness the ability to act in a politically skillful manner (Beckhard, 1995; Birnbaum, 1988; Bolman \& Deal, 1991) while balancing the needs to act entrepreneurially (Cribbin, 1981; Lord \& Maher, 1993) in securing the resources necessary for success (Terry, 1993).

The personal attributes of leaders have also included the ability to act in an authentic (Luthans \& Avolio, 2003; Terry, 1993; Van Direndonck \& Nuijten, 2011) manner, demonstrating honesty (Craig \& Gustafson, 1998; Velasquez, 1992), self-discipline (George, 2003), and trust (Dennis \& Bocarnea, 2005; Graen \& Uhl-Bien, 1995). Furthermore, previous research has identified leader behaviors such as stewardship (Barbuto \& Wheeler, 2006; Sendjaya, Sarros, \& Santora, 2008), benevolence (Velasquez, 1992), and defenders of followers (Lord \& Maher, 1993).

Communication competence. Communication has been identified as one of the primary predictors of emergent leadership (Northouse, 2013). Additionally, communication has also been identified as a predictor of success within established or assigned leadership as well (Bass, 2008). Previous research has established that communication competence has been a necessity for effective leadership (Luthans \& Lockwood, 1984; Van Fleet \& Yukl, 1986; Wilson et al., 1990).

Effective leaders have been shown to be skilled in communication (Olmstead, Cleary, \& Salter, 1973; Stogdill \& Shartle, 1955) including communicating information upwards (Hemphill, 1950; Wilson et al., 1990) as well as disseminating information down to followers 
(Israel, Schulz, Parker, \& Becker, 1998; Jacobs, 1983; Van Fleet \& Yukl, 1986). The exchange of information has been found to be paramount to a leader's success (Fine, 1977; Luthans \& Lockwood, 1984).

Leaders have also been found to seek (Metcalfe, 1984) and process (Hitt et al., 1983; Olmstead, Cleary, Lackey, \& Salter, 1976) information through listening (Greenleaf, 1970) and other acquisition methods (Olmstead, Baranick, \& Elder, 1978). Once obtained leaders clarify information (Yukl, 1998) to facilitate appropriate implementation (Farr, 1982; Jacobs, 1983).

Supporting others. In their research, Yukl, Gordon, and Taber (2002) defined supporting as, "showing consideration, acceptance, and concern for the needs and feelings of other people" (p. 20). Several researchers have indicated that one of the primary responsibilities of leaders is to provide support to their followers (Hersey \& Blanchard, 1969; House \& Mitchell, 1974; Yukl, 1998).

Leaders that serve their followers have been seen as more accountable (Van Dierendonck \& Nuijten, 2011) with higher levels of obligation (Graen \& Uhl-Bien, 1995) and publicspiritedness (Velasquez, 1992). Leaders that support and serve their followers have alsobeen found to be more effective in helping those followers solve problems (Shultz, 1961) and through the process provide developmental opportunities (Van Wart, 2003).

However, researchers have also cautioned against the overuse of support for followers. In cases where follower responsibility is deferred to the leader, the leader has been seen as a scapegoat or surrogate for individual responsibility (Krech \& Crutchfield, 1948). Consequently there has been a necessity for effective leaders to voluntarily subordinate their wants for the needs of their followers (Sendjaya et al., 2008) without checking out or becoming detached from the execution of the process (Metcalfe, 1984).

Fostering and maintaining good relations. One of the core responsibilities of a leader has been identified as facilitating cooperation and team work (Van Fleet \& Yukl; 1986; Yukl \& Nemeroff, 1979; Wells, 1997). Leaders have been found to achieve group cohesiveness (Bonjean \& Olson, 1964) by knowing followers (Helme, 1974), actively maintaining interpersonal relationships (Wofford, 1971), and encouraging group preservation activities (Misumi, 1985).

The ability to network has been identified as a method effective leaders use to foster and maintain good relations (Senge, 1995; Yukl, 1998). To cultivate good relations with followers (Sayles, 1981), effective leaders have been found to socialize (Luthans \& Lockwood, 1984; Ohmstead et al., 1973) and actively attempt to draw individuals in (Metcalfe, 1984). Effective leaders have been found to be adept at interacting with both followers (Bennett, 1971; Bowers \& Seashore, 1972) as well as outsiders (Luthans \& Lockwood, 1984).

Cultivating and tending to relationships has been a prominent theme in the literature (Blake \& Mouton, 1964; George, 2003; Pigg, 1999; Stogdill \& Shartle, 1955). Researchers have found that effective leaders act in a transparent manner (Walumbwa et al., 2008), actively seeking to facilitate follower relationships (Har-Evan, 1992; Quinn, Dixit, \& Fareman, 1987; Yukl \& Nemeroff, 1979) and integrate followers into the group (Israel et al., 1998). One 
intended result of such behavior has been to foster a sense of fidelity among followers (Velasquez, 1992); however, other researchers have cautioned against too much emphasis being placed on fostering and maintaining good relations at the detriment of other group needs (Miller, 1973; Reddin, 1977). Specifically, Heifetz (1994) identified a tendency towards work avoidance if followers are provided too much accommodation.

Managing conflict. A characteristic of effective leaders is their ability to manage conflict based on the deleterious effect conflict can have on maintaining good relations among individuals (Luthans \& Lockwood, 1984; Van Fleet \& Yukl, 1986; Yukl \& Nemeroff, 1979). A leader's ability to manage differences (MacKenzie, 1969) and act as an arbitrator (Krech \& Crutchfield, 1948), compromiser (Reddin, 1977) or judge (Haiman, 1951; Mooney \& Reiley, 1931) has been well established. Ultimately a leader's ability to evaluate (Selznick, 1957) and manage conflict (Yukl, 1998) and to act accordingly has been shown to relate to their ability to build and maintain their team (Yukl, 1998).

Understanding, caring, and consideration for others. Providing individualized consideration for followers has been established as one of the primary actions of effective leaders (e.g. Bass \& Avolio, 1990). By valuing people (Laub, 1999) and putting followers first (Liden et al., 2008), effective leaders have demonstrated their empathy (Greenleaf, 1970) and commitment to understanding followers (Katz, 1955).

Numerous authors have applied the term consideration to define the set of leadership activities directed at understanding and caring for others (Fleishman, 1953; Halpin \& Winer, 1957; Reaser, Vaughan, \& Kriner, 1974; Stogdill et al., 1962; Stogdill, Goode, \& Day, 1965). As caretakers (Rothschild, 1993) leaders have been found to seek feelings (Metcalfe, 1984) from followers and provide individualized support accordingly (Podsakoff, MacKenzie, Moorman, \& Fetter, 1990). When leaders fail to actively foster an understanding and caring environment, they have been viewed as bureaucratic (Birnbaum, 1988; Reddin, 1977; Shrivastava \& Nachman, 1989; Wells, 1997) with more focus on shutting others out (Metcalfe, 1984) and retaining their leadership authority (Stogdill et al., 1965).

Leaders that actively seek to understand and care for others are frequently viewed as highly sensitive to both follower and environmental needs (Conger \& Kanungo, 1998). Effective leaders have been found to apply their social judgment skills (Halpin \& Winer, 1957; Mumford et al., 2000) to act with awareness (Berkowitz, 1953; Greenleaf, 1970) and respect for followers (Craig \& Gustafson, 1998; Graen \& Uhl-Bien, 1995). Although the amount of tolerance (Stogdill et al., 1962) and understanding expected among followers has been shown to vary based on cultural heritage (Hofstede, 1980; House, Hanges, Javidan, Dorfman, \& Gupta, 2004) the appreciation for leader consideration and heart has been shown to be almost universally valued (George, 2003).

Fostering happiness. An expected outcome associated with understanding, caring, and consideration of others has been follower happiness (Bass, 2008). Specifically, effective leaders have tended to be alert to morale (Sayles, 1981) and have actively worked to maintain morale (Helme, 1974). One of the primary approaches leaders have sought to address happiness and morale issues has been through the process of healing (Greenleaf, 1970) or emotional healing 
(Barbuto \& Wheeler, 2006; Liden et al., 2008). Emotional healing has been defined as "the act of showing sensitivity to others' personal concerns" (Liden et al., 2008, p. 162). Researchers have found that followers tend to be happier and more content when they are lead in a manner congruent with their personal preferences (Hofstede, 1980; House et al., 2004). As a consequence an effective method to foster happiness among followers has been to attend to follower concerns (Liden et al., 2008).

Motivating others. One of the primary responsibilities of leaders has been to motivate their followers (e.g. Bass \& Avolio, 1990; House, 1977; Kouzes \& Posner, 2002). One of the core factors of transformational leadership has been inspirational motivation where leaders articulate a vision for the future that motivates and inspires their followers to act (Bass \& Riggio, 2006). Other researchers have described a leader's ability to motive followers as encouraging the heart (Kouzes \& Posner, 2002), arousing motives (House, 1977), setting high performance expectations (Podsakoff et al., 1990), providing meaning (Terry, 1993) or hope (Luthans \& Avolio, 2003).

One of the primary mechanisms with which leaders have motivated followers with has been through the use of goals. After setting goals (Farr, 1982; Oldham, 1976, Winter, 1978, Wofford, 1967; Van Fleet \& Yukl, 1986), ensuring the goals are in alignment with the institutional mission (Selznick, 1957), and articulating goals to followers (House, 1977), effective leaders have sought to help followers connect with the goals (Kirk \& Shutte, 2004) and accept group goals (Podsakoff et al., 1990). In the process of achieving a goal, leaders frequently apply appropriate pressure (Wilson et al., 1990) and explain how goals will be met (Bass, 1981).

Inspiring followers has been identified as another effective motivational strategy. When leaders inspire a shared vision (Kouzes \& Posner, 2002) they have been found to foster an environment of loyalty (Gross, 1961), optimism (Luthans \& Avolio, 2003) and commitment (Larson \& LaFasto, 1989). Leader and follower fulfillment (Terry, 1993) and connectivity (Kirk \& Shutte, 2004) have also been associated with inspiring and influencing others (Wong \& Davey, 2007; Yukl, Wall, \& Lepsinger, 1990).

One of the mechanisms researchers have found that leaders use to motivate and inspire their followers with has been through the articulation of a vision (Conger \& Kanungo, 1998; Dennis \& Bocarnea, 2005) and purpose (George, 2003; Pigg, 1999). When leaders provide foresight (Greenleaf, 1970) to their followers and are accurate in forecasting (McGrath, 1964; Stogdill et al., 1962) potentialities, they have been classified as visionaries (Wells, 1997) or visionary heroes (Manz \& Sims, 1993). The strong convictions (Beckhard, 1995) and achievement orientation (House \& Mitchell, 1974) of a leader have also been associated with maintenance (Schein, 1995) and existence (Terry, 1993) of persistent leader and follower identities within the mutual interaction.

Delegating and empowering. Leaders that tend to delegate responsibilities and empower followers in appropriate situations have been found to be perceived as effective (Yukl et al., 2002). Delegating responsibilities to followers is a very common theme within the literature (Hemphill, Siegel, \& Westie, 1951; Hersey \& Blanchard, 1969; Miller, 1973; Tannenbaum \& Schmidt, 1958; Wilson et al., 1990; Van Fleet \& Yukl, 1986; Yukl, 1998). 
Assigning (Olmstead, Lackey, \& Christensen, 1975), organizing (MacKenzie, 1969), coordinating (Gross, 1961), and ensuring task achievement (Winter, 1978) has been viewed as highly related to the delegation of responsibilities.

Typically, delegation has implied that the directionality of responsibility has flowed from the leader to the follower (e.g. Yukl, 1998); however, follower empowerment has been conceptualized as a broadening of the follower domain of responsibility more generally (Liden et al., 2008; Dennis \& Bocarnea, 2005). When leaders have enabled followers to act (Kouzes \& Posner, 2002) and then stood back from the process (Van Dierendonck \& Nuijten, 2011), researchers have found that they tend to create a co-learning environment (Israel et al., 1998) and a sense of community between leader and follower (Greenleaf, 1970; Laub, 1999).

When leaders have shared leadership (Laub, 1999) they tended to be viewed as more collegial (Birnbaum, 1988) and connective in their leadership approach (Kirk \& Shutte, 2004). When delegation and empowerment have been taken to an extreme, researchers have identified laissez-faire leadership as the result (e.g. Bass \& Avolio, 1990). Laissez-faire leaders have tended to be hands off in their approach to such a degree that their involvement has been viewed as inconsequential to the outcomes of their followers (Bass \& Avolio, 1990; Tannenbaum \& Schmidt, 1958).

Promoting collective decision making. Researchers have found that effective leaders frequent engage followers to help make decisions (Van Fleet \& Yukl, 1986) whether through consultation (e.g. Wong \& Davey, 2007), collaboration (e.g. Larson \& LaFasto, 1989) or participation (e.g. House \& Mitchell, 1974). Wong and Davey (2007) identified consulting and involving others as a key factor to leadership effectiveness. The recommendation of these researchers for leaders to actively consult with followers has been reinforced and supported by numerous others (Fine, 1977; Kessing \& Kessing, 1956; Stogdill, Wherry, \& Jaynes, 1953; Tannenbaum \& Schmidt, 1958; Tornow \& Pinto, 1976; Yukl, 1998).

Promoting a collaborative climate (Larson \& LaFasto, 1989) by inviting participation from followers (Metcalfe, 1984) has been found to result in greater perceptions of group decision making (Miller, 1973) and partnerships (Israel et al., 1998). By acting in a participative manner (House \& Mitchell, 1974; Tannenbaum \& Schmidt, 1958) and encouraging participation from followers, effective leaders foster an environment conducive to group decision making (Yukl \& Nemeroff, 1979).

Although promoting collective decision making has been generally found to be associated with effective leadership in the literature (e.g. Bass, 2008), the universality of group decision making has been a topic of contention. Specifically, Hofstede (1980) and House and colleagues (2004) both identified cultural preferences related to power distance and in-group or institutional collectivism. Depending on a follower group's preference for direction or participation, an overabundance of follower participation may be associated with ineffectual leadership (Hofstede, 1980; House et al., 2004).

Developing others. Previous researchers have found that "effective managers take a more active role in developing the skills and confidence of subordinates" (Yukl et al., 2002, p. 
21). The importance of developing followers is a persistent theme within the literature. However, the specific mechanisms for providing development have been varied (Bradford \& Cohen, 1984; Cribbin, 1981; Laub, 1999; MacKenzie, 1969; Reddin, 1977; Winter, 1978; Wong \& Davey, 2007; Yukl, 1998).

Training has been one of the primary channels through which leaders have provided development to their followers (e.g. Kraut, Pedigo, McKenna, Dunnette, 1989; Morse \& Wagner, 1978; Elliott, Harden, Giesler, Scott, \& Euske, 1979). Based on a leader's commitment to the growth of others (Greenleaf, 1970) specific training interventions have included coaching (Hersey \& Blanchard, 1969; Van Fleet \& Yukl, 1986), orientation (MacKenzie, 1969) and operations (Gilbert, 1975) training, as well as on-the-job training (Nealy \& Fiedler, 1968).

Counseling and mentoring have also been identified as methods effective leaders have used to develop others (e.g. Liden et al., 2008; Wells, 1997). Helping followers to grow and succeed (Liden et al., 2008) through advising and counseling (Clement \& Ayres, 1976; Elliott et al., 1979; Farr, 1982; Van Fleet \& Yukl, 1986; Winter, 1978) has been a common theme. Additionally, acting as a mentor for followers and providing nurturing support has been seen as effective (Berkowitz, 1953; Quinn et al., 1987; Wells, 1997).

From a critical developmental perspective, researchers have also found that leaders frequently must provide feedback and potentially mete out discipline (e.g. Bass, 1981; Luthans \& Lockwood, 1984). In concordance with Bass and Avolio (1990), who identified management by exception (both active and passive) as characteristics of transactional leadership, additional authors identified disciplining as the responsibility of a leader (Luthans \& Lockwood, 1984; Oldham, 1976; Winter, 1978). One of the mechanisms a leader may use to manage follower performance (Kraut et al., 1989) is the use of feedback (Wilson et al., 1990). Both receiving (Jacobs, 1983) and providing feedback (Bass, 1981) have been identified as important. However, leaders have also been found to extend beyond the constructive intent of development and stray into attacking (Metcalfe, 1984) and criticizing (Van Fleet \& Yukl; 1986).

Encouraging innovative thinking. One of the methods effective leaders have been found to develop in others has been to encourage their followers to think creatively (e.g. Bass \& Avolio, 1990). Leaders have been found to use their influence with followers (Bonjean \& Olson, 1964; Winter, 1978) to encourage them to challenge the process (Kouzes \& Posner, 2002) and think in a revolutionary manner (Paige, 1977). For example, Bass and Avolio (1990) as well as Podsakoff, MacKenzie, Moorman, and Fetter (1990) identified the factor of intellectual stimulation as a component of effective leadership. Encouraging followers to think beyond the constraints of what a current reality may dictate has been found to be related to follower development and performance (Bass \& Riggio, 2006).

Rewarding and recognizing others. According to Yukl, Gordon, and Taber (2002), "effective leaders provide extensive praise and recognition to subordinates for their achievements and contributions" (p. 21). Numerous researchers have identified the allocation of rewards (Bass, 1981; Miller, 1973; Winter, 1978) and rewarding (Oldham, 1976; Olmstead et al., 1975; Yukl, 1998) as core components of leadership. 
Within the literature, the concept of rewards has been conceptually associated with control mechanisms (MacKenzie, 1969). For example, contingent reward has been described as a form of remuneration apportioned to a follower based on the satisfactory completion of a mutually agreed upon task (Bass \& Avolio, 1990). Correcting and rewarding (Showel \& Peterson, 1958) and serving as purveyor of rewards and punishments (Kretch \& Crutchfield, 1948) has been suggested as similar concepts by other researchers.

Although thematically similar to rewarding, providing praise and recognition has been described as conceptually unique (Van Fleet \& Yukl, 1986; Yukl et al., 2002). Recognizing the contribution of followers (Hempill, 1950; Larson \& LaFasto, 1989; Yukl, 1998; Yukl et al., 1990) without followers having the expectation of an associated reward tends to be more personal and developmentally impactful (Yukl et al., 2002).

\section{Interpersonal Leadership Conceptual Model}

Based on the review of existing literature, a conceptual model of interpersonal leadership has been theorized (Figure 2-1). The model represents an integration of leadership models found in the literature into previous taxonomic recommendations, specifically those of Bass (2008), Fleishman and colleagues (1991), and Yukl and colleagues (2002). Specifically, the model includes three primary areas: entry conditions, core functions, and sub-themes. The items proposed within each area are a direct result of themes identified within the literature analyzed through an interpersonal lens (Bass, 2008). 


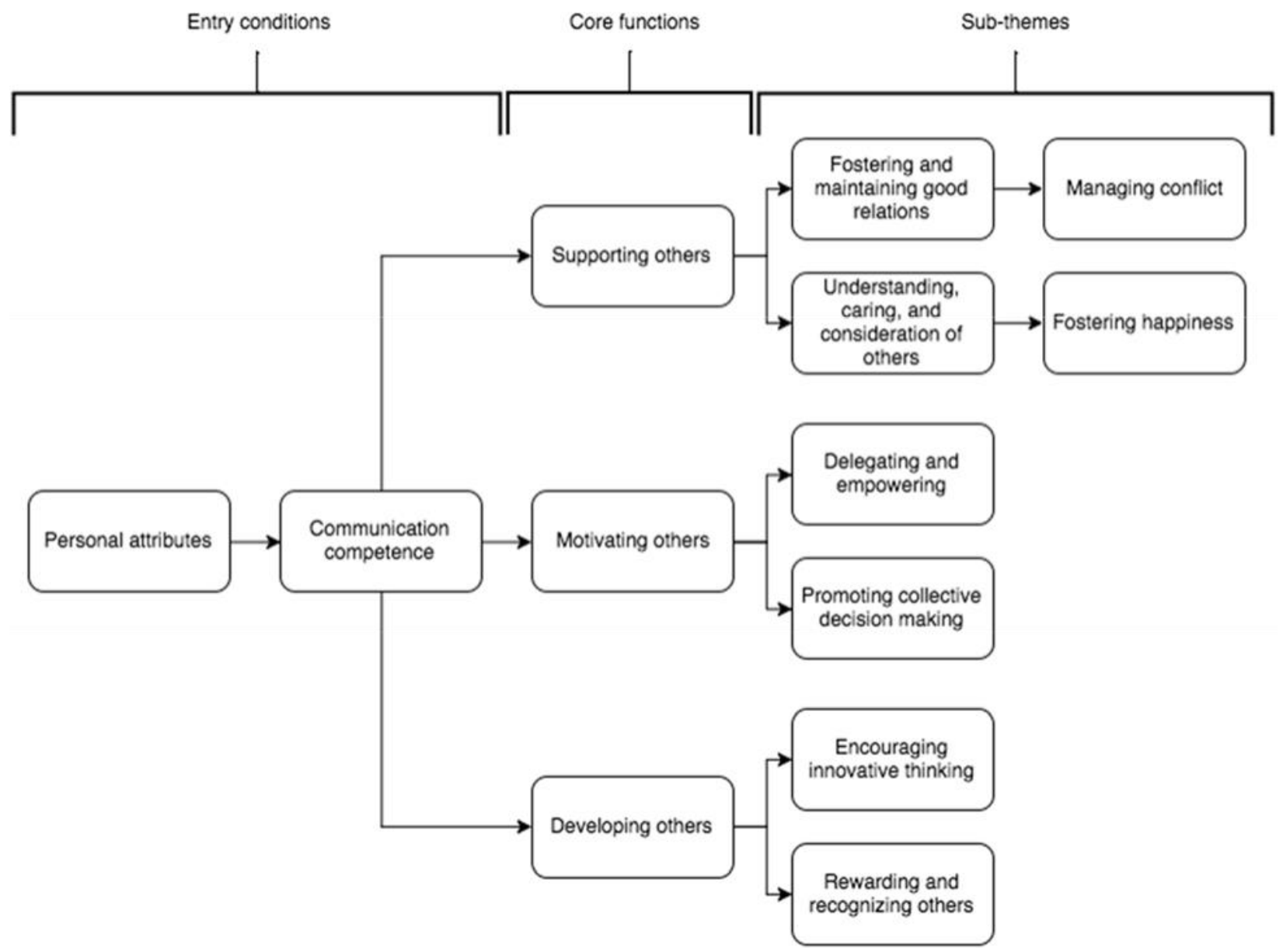

Figure 1. Conceptual model of interpersonal leadership

As an entry condition for interpersonal leadership, an individual must first have the personal attributes necessary to be perceived as a leader by a follower (Bass, 2008). Without satisfying this initial condition it is not possible to effectively influence, or lead, followers. For example, a leader should act as a model (e.g. Bass \& Avolio, 1990; Kouzes \& Posner, 2002) with a sufficient degree of expertise (Mumford et al., 2000), wisdom (Barbuto \& Wheeler, 2006), assertiveness (House et al., 2004), and self-awareness (Walumbwa et al., 2008), to be be considered a leader.

As interpersonal leadership is based in the fundamental leadership unit, leader and follower, without the ability to effectively communicate a leader will not be able to act in a leadership capacity. With no means to direct or influence followers any subsequent leadership effort would be ineffective. Specifically, gathering (Metcalfe, 1984), clarifying (Yukl, 1998), exchanging (Luthans \& Lockwood, 1984), and disseminating (Israel et al., 1998; Van Fleet \& Yukl, 1986) information through appropriate communication channels (Olmstead et al., 1976; Wilson et al., 1990) were identified as primary themes within the literature. 
Extending beyond the necessary entry conditions necessary for interpersonal leadership to occur, a secondary level of core interpersonal leadership functions have been proposed. The three primary interpersonal leadership functions were based on the existing taxonomy recommendations found in the literature. Specifically, supporting others (Yukl et al., 2002), motivating others (Fleishman et al., 1991), and developing others (Fleishman et al., 1991; Yukl et al., 2002).

At the core of effective interpersonal leadership has been the need to effectively motivate others (Fleishman et al., 1991; House, 1977; Kouzes \& Posner, 2002; Terry, 1993). Motivation represents the necessary leadership ability to exert influence required to move from a current condition to some desired alternate condition. According to the literature, effective leaders motivate their followers using a number of various approaches. Numerous methods for motivating others are explored in greater detail previously; however, two sub-themes most relevant to interpersonal leadership, were identified within the literature. Specifically, delegating activities to followers and promoting collective decision making among followers. These subthemes were proposed based on the close relationship required between leader and follower for such motivational approaches to be effective.

A second primary function for interpersonal leaders identified within the literature was supporting others (Yukl et al., 2002). This theme is particularly relevant from an interpersonal perspective based on such leaders' care and consideration of followers (Bass, 2008). Supporting others represents part of the ethos of interpersonal leadership, a desire to not only influence followers to achieve a common goal, but to ensure followers are cared for throughout the process. There are many different manifestations that supporting others may take; however, two of the sub-themes that emerged from the literature were the interpersonal leader's focus on fostering and maintaining good relations, and in particular managing conflict, as well as understanding, caring, and consideration for others, with a particular focus on fostering happiness.

The third primary function for interpersonal leaders was identified as developing others (Fleishmen et al., 1991; Yukl et al., 2002). Similar to supporting others, a focus on developing others represents part of the conceptual uniqueness of interpersonal leadership. Based on the literature it has been proposed that effective interpersonal leaders have a focus on nurturing others throughout the process of goal pursuit and achievement. Within the developing others function two primary sub-themes emerged. First, effective interpersonal leaders encourage innovative thinking among followers; second, such leaders reward and recognize others.

\section{Conclusion}

Although the term interpersonal leadership has been well established within the literature there remains a lack of theoretically derived models that specifically address the comprehensive nature of the underlying leader behaviors and activities (Bass, 2008). The intent of the present article was to attempt to synthesize the existent leadership models, behaviors, and factors to arrive at a coherent conceptual model of interpersonal leadership. 
As a recommended next step, leadership educators are encouraged to adopt, or adapt, the proposed model when educating on interpersonal leadership. For example, the comprehensive model may serve as an appropriate guide for developing a semester long undergraduate curriculum. Alternatively, a purposive selection of a particular content area, such as motivating others, may be helpful when conducting non-formal education with professional audiences.

Future research is recommended to validate the proposed relationships between concepts in the model. Additionally, an extension of the present model linking content areas to outcomes, such as learner performance or satisfaction, may provide implications for teaching. Furthermore, the development and validation of a norm-referenced criterion scale developed according to the proposed model may be valuable from a leader competence and developmental perspective (Pett, Lackey, \& Sullivan, 2003). Nevertheless, a robust conceptual model of interpersonal leadership grounded within the theory base should provide leadership educators with a framework upon with to develop learners accordingly (Andenoro et al., 2013; McKeachie \& Svinicki, 2011).

\section{References}

AACSB (2006). Business and business schools: A partnership for the future. Report of the AACSB International Alliance for Management Education Task Force. Tampa, FL: Association to Advance Collegiate Schools of Business.

AACU (2007). College learning for the new global century: Liberal education and America's promise. Washington, DC: Association of American Colleges and State Universities National Leadership Council.

Andenoro, A. C., Allen, S. J., Haber-Curran, P., Jenkins, D. M., Sowcik, M., Dugan, J. P., \& Osteen, L. (2013). National Leadership Education research agenda 2013-2018: Providing strategic direction for the field of leadership education. Retrieved from Association of Leadership Educators website: http://leadershipeducators.org/ ResearchAgenda.

Avolio, B. J., \& Bass, B. M. (1995). Individual consideration viewed at multiple levels of analysis: A multi-level framework for examining the diffusion of transformational leadership. The Leadership Quarterly,6(2), 199-218. doi:10.1016/1048-9843(95)90035-7

Barbuto Jr., J. E., \& Wheeler, D. W. (2006). Scale development and construct clarification of servant leadership. Group and Organizational Management, 31(300), 326.

Bass, B. M. (1981). Bass and Stogdill's handbook of leadership. New York: The Free press.

Bass, B. M. (2008). The bass handbook of leadership. New York, NY: Free Press.

Bass, B. M., \& Avolio, B. J. (1990). Transformational leadership development: Manual for the multifactor leadership questionnaire. Palo Alto, CA: Consulting Psychologists Press. 
Bass, B. M., \& Farrow, D. L. (1977). Quantitative analyses of biographies of political figures. Journal of Psychology, 97, 281-296.

Bass, B. M., \& Riggio, R. E. (2006). Transformational leadership. New York, NY: Psychology Press.

Beckhard, R. (1995). On future leaders. In F. Hesselbein, M. Goldsmith \& R. Beckhard (Eds.), The leader of the future. San Francisco: Jossey-Bass.

Bennett, E. B. (1971). Discussion, decisions, commitment, and consensus in "group decision". Human Relations, 8, 251-273.

Berkowitz, L. D. (1953). An exploratory study of the roles of aircraft commanders. Brooks Air Force Base, TX: USAF Human Resources Research Center Bulletin.

Birnbaum, R. (1988). Responsibility without authority: The impossible job of the college president. New York: National Center for Postsecondary Governance and Finance, Teachers College, Columbia University.

Blake, R. R., \& Mouton, J. S. (1964). The managerial grid. Houston, TX: Gulf.

Bolman, L. G., \& Deal, T. E. (1991). Reframing organizations. San Francisco, CA: Jossey-Bass Publishers.

Bonjean, C. M., \& Olson, D. M. (1964). Community Leadership: directions of research. Administrative Science Quarterly. (9(3). 278-300.

Bowers, D. B., \& Seashore, S. E. (1972). Predicting organizational group effectiveness with a four factor theory of leadership. Administrative Science Quarterly, 11, 238-263.

Bradford, D. L., \& Cohen, A. R. (1984). The postheroic leader. Training \& Development Journal, 38(1), 40-49.

Burns, J. M. (1978). Leadership. New York: Harper \& Row.

Cheetham, G., \& Chivers, G. (1996). Towards a holistic model of professional competence. Journal of European Industrial Training, 20(5), 20-30. doi:10.1108/03090599610119692

Clement, S. D., \& Ayres, D. B. (1976). The matrix of organizational leadership dimensions. Washington, D.C.: U.S. Army Administration Center.

Conger, J. A., \& Kanungo, R. (1998). Charismatic leadership in organizations. Thousand Oaks, CA: Sage Publications. 
Craig, S. B., \& Gustafson, S. B. (1998). Perceived leader integrity scale: An instrument for assessing employee perceptions of leader integrity. Leadership Quarterly, 9, 127-145.

Cribben, J. J. (1981). Leadership. New York: Amacom.

Dennis, R. S., \& Bocarnea, M. (2005). Development of the servant leadership assessment instrument. Leadership \& Organization Development Journal, 26, 600-615.

Diamond, J. M. (1999). Guns, germs, and steel: The fates of human societies. New York: Norton.

Elliott, M. P., Harden, J. T., Giesler, R. W., Scott, A. C., \& Euske, N. (1979). The process and procedures used for job preparation: Field artillery and infantry, officers and NCOs. Carmel, CA: McFan Frey \& Associates.

Farr, J. L. (1982). A five-factor system of leadership. Greensboro, NC: Farr Associates.

Fine, S. E. (1977). Job analysis for heavy equipment operators. Washington, D.C.: International Union of Operating Engineers.

Fleishman, E. A. (1953). The description of supervisory behavior. Journal of Applied Psychology, 37, 1-6.

Fleishman, E. A., Mumford, M. D., Zaccaro, S. J., Levin, K. Y., Korotkin, A. L., \& Hein, M. B. (1992). Taxonomic efforts in the description of leader behavior: A synthesis and functional interpretation. The Leadership Quarterly, 2(4), 245-287.

George, B. (2003). Authentic leadership: Rediscovering the secrets to creating lasting value. San Francisco: Jossey-Bass.

Gilbert, A. C. (1975). Dimensions of certain army officer positions derived by factor analysis. Alexandria, VA: U.S. Army Research Institute.

Graen, G., \& Uhl-Bien, M. (1995). Relationship-based approach to leadership: Development of leader-member exchange (LMX) theory over 25 years: Applying a multi-level multidomain perspective. Leadership Quarterly, 6, 219-247.

Greenleaf, R. K. (1970). The servant as leader. Indianapolis, IN: Robert K. GreenleafCenter.

Gross, E. (1961). Dimensions of leadership. Personnel Journal, 40,213-218.

Haiman, F. S. (1951). Group leadership and democratic action. Boston: Houghton Mifflin. 
Halpin, A. W., \& Winer, J. B. (1957). A factorial study of the leader behavior descriptions. In R. M. Stogdill, \& A. E. Coons (Eds.), Leader behavior: Its description and measurement (pp. 39-51). Columbus, OH: Ohio State University, Bureau of Business Research.

Har-Evan, S. (1992). Four models of leadership persuade you. Seminar on Leadership, Tel Aviv: Open University.

Heifetz, R. (1994). Leadership without easy answers. Cambridge, MA: Harvard University Press.

Helme, W. H. (1974). Leadership research findings applied to the officer personnel management system. Alexandria, VA: U.S. Army Research Institute.

Hemphill, J. K. (1950). Leader behavior description. Columbus, OH: Ohio State Personnel Research Board.

Hemphill, J. K., Siegel, A., \& Westie, C. W. (1951). An exploratory study of relations between perceptions of leader behavior, characteristics, and expectations concerning the behavior of ideal leaders. Columbus, OH: Ohio State University, Personnel Research Board.

Hersey, P., \& Blanchard, K. H. (1969). Management of organizational behavior. Englewood Cliffs, NJ: Prentice-Hall.

Hitt, M., Middlemist, R., \& Mathis, R. (1983). Management: Concepts and effective practice. New York: West Publishing Co.

Hofstede, G. (1980). Culture's consequences: International differences in work related values. Beverly Hills, CA: Sage.

House, R. J. (1977). A 1976 theory of charismatic leadership. In J. G. Hunt, \& L. L. Larson (Eds.), Leadership: The cutting edge. Carbondale, IL: Southern Illinois University Press.

House, R. J., Hanges, P. J., Javidan, M., Dorfman, P. W., \& Gupta, V. (2004). Culture, leadership, and organizations: The GLOBE study of 62 societies. Thousand Oaks, CA: Sage.

House, R. J., \& Mitchell, T. R. (1974). Path-goal theory of leadership. Journal of Contemporary Business, 3, 81-97.

Hunt, J. G., Boal, K. B., \& Sorenson, R. L. (1990). Top management leadership: Inside the black box. Leadership Quarterly, 1, 41-65. 
Israel, B. A., Schulz, A. J., Parker, E. A., \& Becker, A. B. (1998). Review of community-based research: Assessing partnership approaches to improve public health. Annual Review of Public Health, 19, 173-202.

Jacobs, O. (1983). Leadership requirements for the air land battle. Paper Presented at the Leadership on the Future Battle Field Symposium, Texas Tech University, Lubbock, TX.

Javidan, M., \& Dastmalchian, A. (1993). Assessing senior executives: The impact of context on their roles. The Journal of Applied Behavioral Science, 29, 289-305.

Judge, T. A., \& Bono, J. E. (2000). Five-factor model of personality and transformational leadership. The Journal of Applied Psychology, 85(5), 751-765. doi:10.1037/00219010.85 .5 .751

Judge, T. A., Bono, J. E., Ilies, R., \& Gerhardt, M. W. (2002). Personality and leadership: A qualitative and quantitative review. Journal of Applied Psychology, 87(4), 765-780. doi:10.1037/0021-9010.87.4.765

Katz, R. L. (1955). Skills of an effective administrator. Harvard Business Review, 33(1), 33-42.

Kessing, F. M., \& Kessing, M. M. (1956). Elite communication in Samoa: A study of leadership. Stanford, CA: Stanford University Press.

Kirk, P., \& Shutte, A. M. (2004). Community leadership development. Community Development Journal, 39(3), 234-251.doi:10.1093/cdj/bsh019

Kouzes, J. M., \& Posner, B. Z. (2002). The leadership challenge (3rd ed.). San Francisco: Jossey-Bass.

Kouzes, J. M., \& Posner, B. Z. (2010). The truth about leadership: The no-fads, heart-of-thematter facts you need to know. San Francisco: Jossey-Bass.

Kraut, A. I., Pedigo, P. R., McKenna, D. D., \& Dunnette, M. D. (1989). The role of the manager: What's really important in different management jobs. Academy of Management Executive, 3, 286-293.

Krech, D., \& Crutchfield, R. S. (1948). Theory and problems of social psychology. New York: McGraw-Hill.

Larson, C. E., \& LaFasto, F. M. J. (1989). Teamwork: What must go right; what can go wrong. Newbury Park, CA: Sage.

Laub, J. A. (1999). Assessing the servant organization: Development of the servant organizational leadership assessment (SOLA) instrument (Ed.D.). Available from ProQuest Dissertations \& Theses Full Text. (304517144). Retrieved from http://search.proquest.com/docview/304517144? accountid=10920 
Liden, R. C., Wayne, S. J., Zhao, H., \& Henderson, D. (2008). Servant leadership: Development of a multidimensional measure and multi-level assessment. Leadership Quarterly, 19, 161-177.

Lord, R. G., De Vader, C. L., \& Alliger, G. M. (1986). A meta-analysis of the relation between personality traits and leadership perceptions: An application of validity generalization procedures. Journal of Applied Psychology, 71(3), 402-410.

Lord, R. G., \& Maher, K. J. (1991). Leadership and information processing: Linking perceptions and performance. Boston: Unwin Hyman.

Lord, R. G., \& Maher, K. J. (1993). Leadership and information processing: Linking perceptions and performance. New York: Routledge.

Luthans, F., \& Avolio, B. J. (2003). Authentic leadership development. In K. S. Cameron, J. E. Dutton \& R. E. Quinn (Eds.), Positive organizational scholarship (pp. 241-258). San Francisco: Berrett-Koehler.

Luthans, F., \& Lockwood, D. L. (1984). Toward an observation system for measuring leader behavior in natural settings. In J. G. Hunt, D. Hosking, C. A. Schriesheim \& R. Stewart (Eds.), Leaders and managers: International perspectives on managerial behavior and leadership (pp. 117-141). New York: Pergamon Press.

Mackenzie, R. A. (1969). The management process in 3-D. Harvard Business Review, 47, 80-87.

MacKenzie, S., Podsakoff, P., \& Rich, G. (2001). Transformational and transactional leadership and salesperson performance. Journal of the Academy of Marketing Science, 29, 115-134.

Manz, C. C., \& Sims Jr., H. P. (1993). Superleadership: Beyond the myth of heroic leadership. In D. Bohl (Ed.), New dimensions in leadership. New York: American Management Association.

McKeachie, W., \& Svinicki, M. (2013). McKeachie's teaching tips. Cengage Learning.

McGrath, J. E. (1964). Leadership behavior: Some requirements for leadership training. Office of Career Development, U.S. Civil Service Commission.

Metcalfe, B. A. (1984). Microskills of leadership: A detailed analysis of the behaviors of managers in the appraisal interview. In J. G. Junt, D. M. Hosking, C. A. Schriesheim \& R. Stewart (Eds.), Leaders and managers: International perspectives on managerial behavior and leadership. New York: Permagon Press.

Miller, J. A. (1973). The hierarchical structure of leadership behaviors. (Technical Report v64). Rochester, NY: University of Rochester. 
Mintzberg, H. (1973). The nature of managerial work. New York: Harper \& Row.

Misumi, J. (1985). The behavioral science of leadership. Ann Arbor, MI: University of Michigan.

Mooney, J. D., \& Reiley, A. C. (1931). Onward industry: The principles of organization and their significance to modern industry. New York: Harper.

Morse, J. J., \& Wagner, F. R. (1978). Measuring the process of managerial effectiveness. Academy of Management Journal, 21, 23-35.

Mumford, M. D., Zaccaro, S. J., Harding, F. D., Jacobs, T. O., \& Fleishman, E. A. (2000). Leadership skills for a changing world: Solving complex social problems. The Leadership Quarterly, 11(1), 11-35.

Nealey, S. M., \& Fiedler, F. E. (1968). Leadership functions of middle managers. Psychological Bulletin, 5, 313-329.

Northouse, P. G. (2013). Leadership: Theory and practice (6th ed.). Thousand Oaks: Sage Publications.

Oldham, G. R. (1976). The motivational strategies used by supervisors: Relationships to effectiveness indicators. Organizational Behavior and Human Performance, 15, 66-86.

Olmstead, J. A., Baranick, M. J., \& Elder, L. (1978). Research on training for brigade command groups: Factors contributing to unit combat readiness. Alexandria, VA: Human Resources Research Organization.

Olmstead, J. A., Cleary, F. D., \& Salter, J. A. (1973). Leadership activities of company command officers. Alexandria, VA: Human Resources Research Organization.

Olmstead, J. A., Cleary, F. D., Lackey, L. L., \& Salter, J. A. (1976). Functions of battalion command groups. (). Alexandria, VA: Human Resources Research Organization.

Olmstead, J. S., Lackey, L. L., \& Christenson, H. E. (1975). Leadership actions as evaluated by experienced company grade officers. Alexandria, VA: Human Resources Research Organization.

Paige, G. D. (1977). The scientific study of political leadership. New York: Free Press.

Pett, M. A., Lackey, N. R., \& Sullivan, J. J. (2003). Making sense of factor analysis: The use of factor analysis for instrument development in health care research. Thousand Oaks, CA: Sage.

Pigg, K. E. (1999). Community leadership and community theory: A practical synthesis. Journal of Community Development Society, 30(2), 196-212. 
Podsakoff, P. M., MacKenzie, S. B., Moorman, R. H., \& Fetter, R. (1990). Transformational leader behaviors and their effects on followers' trust in leader, satisfaction, and organizational citizenship behaviors. The Leadership Quarterly, 1(2), 107-142. doi:10.1016/1048-9843(90)90009-7

Quinn, R. E., Dixit, N., \& Faerman, S. R. (1987). Perceived performance: Some archetypes of managerial effectiveness and ineffectiveness. Albany, NY: State University of New York at Albany, Nelson A. Rockefeller College of Public Affairs and Policy, Institute for Government and Policy Studies.

Reaser, J. M., Vaughan, M. R., \& Kriner, R. E. (1974). Military leadership in the seventies: A closer look at the dimensions of leadership behavior. Alexandria, VA: Human Resources Research Organization.

Reddin, W. J. (1977). An integration of leader-behavior typologies. Group \& Organization Studies, 25(3), 282-295.

Rogers, E. M. (2003). Diffusion of innovations (5th ed.). New York, NY: FreePress.

Rothschild, W. E. (1993). Risktaker, cartaker, surgeon, undertaker: The four faces of strategic leadership. New York: John Wiley \& Sons.

Sayles, L. R. (1981). Leadership: What effective managers usually do and how they do it. New York: McGraw-Hill.

Schein, E. (1995). Organizational and managerial culture as a facilitator or inhibitor of organizational transformation. (No. Working Paper 3831). Cambridge, MA: MIT Sloan School of Management.

Selznick, P. (1957). Leadership in administration: A sociological interpretation. Evanston, IL: Row \& Peterson.

Sendjaya, S., Sarros, J. C., \& Santora, J. C. (2008). Defining and measuring servant leadership behaviour in organizations. Journal of Management Studies, 45(2), 402-424.

Senge, P. M. (1995). Reflection of leadership: How Robert K. Greenleaf's theory of servantleadership influenced today's top management thinkers. Robert Greenleaf's legacy: Anew foundation for twenty-first century institutions (pp. 217-240). New York, NY: John Wiley and Sons.

Showel, M., \& Peterson, C. W. (1958). A critical incident study of infantry, airborne, and armored junior noncommissioned officers. Alexandria, VA: Human Resources Research Organization.

Shrivastava, P., \& Nachman, S. A. (1989). Strategic leadership patterns. Strategic Management Journal, 51-66. 
Shultz, W. C. (1961). The ego theory and the leader as completer. In L. Petrullo, \& B. Bass (Eds.), Leadership and interpersonal behavior. New York: Holt, Reinhart, \& Winston.

Stogdill, R. M., Goode, O. S., \& Day, D. R. (1962). New leader behavior description subscales. Journal of Psychology, 54, 259-269.

Stogdill, R. M., Goode, O. S., \& Day, D. R. (1965). The leader behavior of university presidents. Columbus, $\mathrm{OH}$ : Ohio State University, Bureau of Business Research.

Stogdill, R. M., \& Shartle, C. L. (1955). Methods in the study of administrative leadership. Columbus, $\mathrm{OH}$ : Ohio State University.

Stogdill, R. M., Wherry, R. J., \& Jaynes, W. E. (1953). Patterns of leader behavior: A factorial study of navy officer performance. Columbus, $\mathrm{OH}$ : Ohio State University.

Tannenbaum, R., \& Schmidt, W. H. (1958). How to choose a leadership pattern. Harvard Business Review, 36(2), 95-101.

Terry, R. W. (1993). Authentic leadership: Courage in action. San Francisco: Jossey-Bass.

Tornow, W. W., \& Pinto, P. R. (1976). The development of a managerial job taxonomy: A system for describing, classifying and evaluating executive positions. Journal of Applied Psychology, 61, 410-418.

Van Dierendonck, D., \& Nuijten, I. (2011). The servant leadership survey: Development and validation of a multidimensional measure. Journal of Business and Psychology, 26(3), 249-267.

Van Fleet, D. D., \& Yukl, G. A. (1986). Military leadership: An organizational behavior perspective. Greenwich, CT: JAI Press.

Van Wart, M. (2003). Public-sector leadership theory: An assessment. Public Administration Review, 63(2), 214-228.

Velasquez, M. G. (1992). Business ethics: Concepts and cases (3rd ed.). Englewood Cliffs, NJ: Prentice Hall.

Walumbwa, F. O., Avolio, B. J., Gardner, W. L., Wernsing, T. S., \& Peterson, S. J. (2008). Authentic leadership: Development and validation of a theory-based measure. Journal of Management, 34(1), 89-126.

Wells, S. (1997). From sage to artisan: The nine roles of the value-driven leader. Palo Alto: Davies-Black Publishing. 
Whitehead, G. (2009). Adolescent leadership development building a case for an authenticity framework. Educational Management Administration \& Leadership, 37(6), 847-872.

Wilson, C. L., O'Hare, D., \& Shipper, F. (1990). Task cycle theory: The processes of influence. In K. E. Clark, \& M. B. Clark (Eds.), Measures of leadership (pp. 185-204). West Orange, NJ: Leadership Library of America.

Winter, D. G. (1978). Navy leadership and management competencies: Convergence among tests, interviews, and performance ratings. Boston, MA: McBer \& Company.

Wofford, J. C. (1967). Behavior styles and performance effectiveness. Personnel Psychology, 20, 461-495.

Wofford, J. C. (1971). Factor analysis of managerial behavior variables. Journal of Applied Psychology, 54, 169-173.

Wong, P. T. P., \& Davey, D. (2007). Best practices in servant leadership. Paper Presented at the Servant Leadership Research Roundtable, Regent University, Virginia Beach, VA.

Yukl, G. (1998). Leadership in organizations (4th ed.). Englewood Cliffs, NJ: Prentice-Hall.

Yukl, G., Gordon, A., \& Taber, T. (2002). A hierarchical taxonomy of leadership behavior: Integrating a half century of behavior research. Journal of Leadership \& Organizational Studies, 9(1), 15-32.

Yukl, G. A., \& Nemeroff, W. (1979). Identification and measurement of specific categories of leadership behavior: A progress report. In J. G. Hunt, \& L. L. Larson (Eds.), Crosscurrents in leadership (pp. 164-200). Carbondale, IL: Southern Illinois University Press.

Yukl, G., Wall, S., \& Lepsinger, R. (1990). Preliminary report on validation of the managerial practices survey. In K. E. Clark, \& M. B. Clark (Eds.), Measures of leadership (pp. 223238). West Orange, NJ: Leadership Library of America.

\section{Author Biographies}

Kevan Lamm, Ph.D., is the president of LR Brand, Inc. a private consulting firm specializing in evaluation, operational execution, and talent development.

Alexa Lamm, Ph.D., is an assistant professor in the Department of Agricultural Education and Communication and Associate Director of the UF/IFAS Center for Public Issues Education at the University of Florida.

Hannah Carter, Ph.D., is an associate professor of leadership education in the Department of Agricultural Education and Communication at the University of Florida. Within this 
appointment, she is the Director of the Wedgworth Leadership Institute for Agriculture and Natural Resources and also the interim director for the UF/IFAS Center for Leadership. 